ENTREPRENEURSHIP AND SUSTAINABILITY ISSUES

ISSN 2345-0282 (online) http://jssidoi.org/jesi/

2020 Volume 8 Number 2 (December)

http://doi.org/10.9770/jesi.2020.8.2(7)
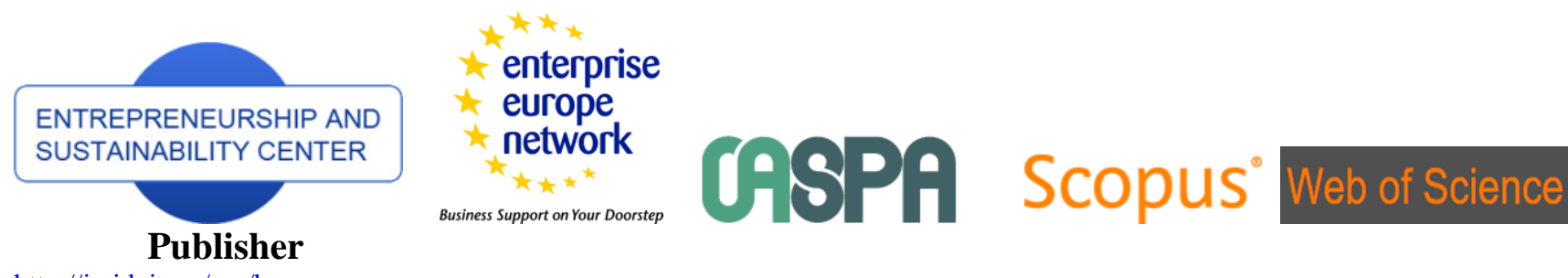

http://jssidoi.org/esc/home

Business Support on Your Doorstep

\title{
DEVELOPMENT OF PROXIMITY IN CLUSTER ORGANIZATIONS
}

\author{
Anna Maria Lis \\ Gdańsk University of Technology, Gabriela Narutowicza 11/12, 80-233 Gdansk, Poland \\ E-mail: $\underline{\text { Anna.Lis@zie.pg.gda.pl }}$
}

Received 18 March 2020; accepted 20 July 2020; published 30 December 2020

\begin{abstract}
Sustainable development in cluster organizations (COs) is most fully manifested in the synergy effect. In turn, the synergy effect is achieved thanks to the development of proximity among cluster entities. The purpose of the paper is to test two conceptual models reflecting relations between selected dimensions of proximity in cluster organizations. The author reports the findings of a quantitative study conducted in four COs. The basic technique for collecting data was an online questionnaire. Both theoretical models were tested using Structural Equation Modelling.The research goes beyond the state-of-the-art knowledge in the concept of industrial cluster by exposing a broader view on cluster cooperation, which is developed on the basis of geographical proximity, and simultaneously contributes to the development of proximity in other dimensions: social, competence and organizational.
\end{abstract}

Keywords: cluster; cluster organization; cluster cooperation; proximity

Reference to this paper should be made as follows: Lis, A.M. 2020. Development of proximity in cluster organizations. Entrepreneurship and Sustainability Issues, 8(2), 116-132. http://doi.org/10.9770/jesi.2020.8.2(7)

JEL Classifications: L22, R10, R11

\section{Introduction}

The review of theoretical concepts regarding the issue of cooperation among economic entities anchored in a specific location shows their strong connection with a broad understanding of the category of proximity. It turns out that regardless of whether Marshall's industrial districts or other theories perceiving the region as a hub of knowledge (including the cluster concept) are analyzed, each of these ideas uses elements directly related to the concept of proximity. This is important because without "proximity", many elements that make up the definitions of subsequent forms of the coexistence of economic entities operating in a given territory would be beyond the reach of influence of the entities managing them. As numerous studies show, proximity in various dimensions enables synergy to be achieved. According to Porter's approach, the cluster is a system of mutually related companies and institutions, and its value as a whole is greater than the sum of the values of its individual parts (Porter, 2008). Cooperation in clusters, based on geographical proximity facilitating the development of strong and lasting interactions within the cluster leads to the synergy effect, which is the basis for the sustainable 


\section{ENTREPRENEURSHIP AND SUSTAINABILITY ISSUES}

ISSN 2345-0282 (online) http://jssidoi.org/jesi/ 2020 Volume 8 Number 2 (December) http://doi.org/10.9770/jesi.2020.8.2(7)

development of the cluster and its constituent entities, but also for the region in which the cluster operates. Porter clearly emphasizes the competitive advantage of clusters, claiming that cooperation in clusters has a positive effect on increasing the efficiency, innovation and entrepreneurship of the enterprises operating in clusters. Despite the accompanying competition risk, cluster cooperation could therefore be considered as one of the forms of modern entrepreneurship that could help in the sustainable development of enterprises, especially those representing the SME sector (Havierniková \& Kordoš, 2019). "Proximity" provides a specific concretization of the features, processes and mechanisms underlying the business activity of entities, and thus facilitates their understanding, increasing the possibility of effective management. The knowledge of proximity and its dimensions, as well as the ability to apply it in practice, therefore, seems to be extremely important for the management of both individual enterprises and groups of enterprises associated in higher-order organizations, including cluster organizations (COs).

Meanwhile, the concept of proximity, although cognitively attractive, is still a scarcely explored area in management sciences. The literature especially lacks publications that would connect the concept of proximity with cluster organizations (not clusters). As a result of a systematic review of the literature, no publication was found that would associate different dimensions of proximity with COs. In the databases (Web of Science Core Collection and Scopus), only publications combining the issue of proximity with the concept of clusters were found (e.g. Yamada \& Kawakami, 2015; Levy \& Talbot, 2015; Bahlmann, 2016). This is also due to the fact that most publications in scientific literature refer to clusters viewed in geographical or economic categories, yet only a few of them address clusters as organizations. Insufficient recognition of the issues related to the development of cooperation in COs, and their poor description in the literature as well as the lack of publications combining the concept of COs with the concept of proximity, which is a visible juxtaposition regarding the dynamic development of these structures in the world, indicate a huge cognitive, research and methodological gap.

The paper reports the findings of a quantitative study based on an analysis of four COs from the metal and the ICT industries in Poland concerning the dynamics of proximity and its role in the development of cooperative relationships in COs. The study presented in this paper should be considered as a continuation of the author's earlier study on the development of proximity in COs, in which priority was given to qualitative research (Lis, 2018). The aim of the current study was to test two research hypotheses formulated as part of the concept of proximity, developed on the basis of the qualitative research, reflecting the relations between the individual dimensions of proximity in COs.

The research goes beyond the state-of-the-art knowledge in the concept of industrial clusters (with a particular emphasis on cluster organizations) by exposing a broader view of cluster cooperation, which is, on the one hand, developed on the basis of specific dimensions of proximity (especially geographical proximity), and on the other, contributes to the development of proximity in other dimensions. Although the study was conducted in Poland, it offers findings that may be verified in other countries, especially those in the EU where cluster policies are implemented, focused on cluster development by means of COs.

The paper is organized in the following manner. Firstly, the paper contains a literature review on proximity, and its dynamics and connection with industrial clusters. Secondly, it includes details with regard to the methodology: conceptual assumptions and research hypotheses, operationalization, the research sample, and the techniques for collecting and analyzing data. The third part reports the empirical results. Finally, there is a discussion, followed by conclusions with the study contributions, limitations and directions for future research. 


\section{ENTREPRENEURSHIP AND SUSTAINABILITY ISSUES}

ISSN 2345-0282 (online) http://jssidoi.org/jesi/ 2020 Volume 8 Number 2 (December) http://doi.org/10.9770/jesi.2020.8.2(7)

\section{Literature review}

\subsection{Proximity and its dimensions}

The use of "proximity" for scientific research and analysis in the economic field began to gain popularity at the end of the twentieth century. Since then, more and more scientific works on this issue have been produced. According to the latest systematic review of the literature, around 2,8 thousand papers on proximity are identified in the Web of Science Core Collection database, whereas in the Scopus database this number is even higher (almost 4,000). In the 1980s and early 1990s, the literature on proximity was dominated by an approach that concentrated on the relationships within an organization (Monge et al., 1985; Rice \& Aydin, 1991). Since the mid-1990s, the focus of attention shifted to the inter-organizational context of proximity (Klimas, 2011; 2020). The development of the concept of "proximity" as well as its dissemination in the literature was largely influenced by the French school of proximity (Rallet \& Torre, 1999; Gilly \& Torre, 2000; Torre \& Rallet, 2005), emphasizing that proximity is the key element in the process of coordinating economically oriented activities. It facilitates the transfer of knowledge, improves the mechanisms of providing strategic information and has a positive effect on conflict resolution (Boschma et al., 2014). In addition, proximity is considered to be a factor that significantly improves the processes of cooperation among entities (Petruzzelli et al., 2009), reduces uncertainty in relationships (Boschma, 2005a; Paci et al., 2014) and remains conducive to the development of innovation.

The term "proximity" is merely a common term that refers to a set of specific aspects; however, the list of these aspects is neither complete nor unambiguous. Researchers most often refer to the five dimensions of proximity proposed by Boschma: geographical, cognitive, social, organizational and institutional proximity (Boschma 2004; 2005a; 2005b; Boschma \& Frenken, 2010; Boschma et al., 2014; Balland et al., 2015). In terms of the number of publications in the above-mentioned databases referring to individual dimensions of proximity, geographical proximity takes first place. Second place is occupied by social proximity, followed by organizational then cognitive proximity, with the institutional dimension at the end of the list (Lis, 2018).

Geographical proximity is characterized by slight ambiguity (Knoben \& Oerlemans, 2006). Relatively, the most common understanding of geographical proximity is Boschma's definition, according to which it is defined as the physical distance between actors, and this distance can be understood as a distance measured in specific units or as the time necessary to move from point A to point B (Boschma et al., 2014; Boschma, 2005a). Social proximity refers to relationships among entities, characterized by the trust created due to at least one of the following reasons: kinship ties, bonds of friendship, ties based on the past, personal experience connecting the analyzed entities (Boschma, 2005a; Heringa et al., 2014; Broekel \& Boschma, 2012). The positive impact of social proximity on the results of cooperation among entities has already been quite well described in the literature, with a particular emphasis on the impact of relationships on the exchange of tacit knowledge (Boschma, 2005a; Boschma et al., 2014; Doloreux, 2002) and higher innovation (Tremblay et al., 2003; Paci et al., 2014; Guerini et al., 2013), and therefore factors that can be associated with cognitive proximity. The most general understanding of cognitive proximity indicates that this term is simply the similarity in the processes of receiving, interpreting, understanding and assessing the world (Wuyts et al., 2005). Cognitive proximity can also be understood as the degree of convergence of the knowledge systems of the analyzed entities. The importance of cognitive proximity manifests itself in many issues, but the key aspect to which this dimension of proximity applies is the process of knowledge exchange and creation. It is an element necessary for the proper functioning of communication processes and knowledge transfer mechanisms, as it enables the accurate identification, proper interpretation and effective use of new elements in the knowledge system (Cohen \& Levinthal, 1990). The designations of the last two identified dimensions of proximity - organizational and institutional - overlap to a large extent, but maintaining the separateness of these categories allows their characteristic features to be captured. Using the existing understanding of organizational proximity (Knoben \& Oerlemans, 2006; Boschma, 2005a; Boschma et 


\section{ENTREPRENEURSHIP AND SUSTAINABILITY ISSUES}

ISSN 2345-0282 (online) http://jssidoi.org/jesi/ 2020 Volume 8 Number 2 (December) http://doi.org/10.9770/jesi.2020.8.2(7)

al., 2014), it can be defined as the suitability of two or more organizations in terms of both the logic of similarity (e.g. the similarity of internal structures and processes, the degree of inter-organizational dependencies) and the logic of belonging (sharing a specific space of relations, e.g. in participation in the same higher-order organizations as the $\mathrm{CO}$ ). In turn, most approaches to institutional proximity are based on the concept of "institution" proposed by North (North, 1990). This dimension of proximity can be understood as the degree of overlap between the formalized elements of normative order (legal provisions and administrative requirements in force in a given area) and the informal system of values, thinking and behavioral patterns within which the analyzed entity and the entities associated with it operate.

\subsection{Dynamics of proximity}

A characteristic feature of each of the created proximity dimensions is their dynamic nature. The static perspective gives "proximity" primacy over relationships, while in the dynamic perspective, the analysis focuses on conditions in which "proximity" becomes the source of relationships or the relationships produce "proximity". There is no dimension of proximity that would function in perfect isolation from the other dimensions. This means that the dynamics of a particular aspect of proximity are influenced not only by what happens within that particular aspect, but by anything that occurs in each of the other dimensions. The dimensions of proximity create a structured system in which each element is related to the others, and the changes occurring in one part of the system affect different areas with different strengths. From the point of view of dynamics, it is also important that each of the dimensions of proximity differs from the others not only in the nature of the relationships it describes, but also in a certain "susceptibility" to change. This means that some of the dimensions of proximity are much more flexible (they are more often and easily changed), while others react with a delay and a smaller scope of introduced modifications. The literature review shows that the dimension relatively the most prone to change is social proximity (Dosi \& Nelson, 1994), and the hardest to change, relatively, is the geographical dimension (Stam, 2007).

Geographical proximity is a unique dimension of proximity, especially in the context of COs. This is the most difficult to modify, but also the most basic and earliest recognized type of proximity. Geographical proximity can stimulate other dimensions of proximity, and is often replaced by them (Boschma, 2005a). Geographical proximity, although not a prerequisite for the establishment of cooperative relationships among economic entities, may act as a factor supporting the formation of such relationships in other aspects of proximity. The effect of a physical "neighborhood" will almost always contribute to the formation of a specific "overlay" between the spatial dimension of proximity and its other dimensions (Malmberg \& Maskell, 2006). This applies especially to proximity in the social dimension (Hansen, 2015). However, this is not obvious in the case of cognitive and organizational proximity, which have the feature of the substitutability of geographical proximity. Geographical proximity can strengthen cognitive proximity (Paci et al., 2014; Guerini et al., 2013; Boschma, 2005a). This gains importance especially in cases where establishing cooperation is accompanied by a low level of cognitive proximity among potential partners. With a high level of cognitive proximity, however, the relevance of geographical proximity significantly decreases (Singh, 2005). Compatible knowledge bases of cooperating entities allow effective cooperation even when the involved partners are significantly distant from each other (Hansen, 2015). Geographical proximity is not a catalyst for processes of the constitution and strengthening of organizational proximity - both in its intra- and inter-organizational dimension. In addition, when organizational proximity reaches a high level, i.e. when there is a detailed and precise division of tasks within the organization, coordinated by a strong, central core and partners share common experiences (an element of cognitive proximity), the need to be in geographical proximity may disappear (Rallet \& Torre, 1999).

The lack of common ground resulting from the nature of the location of the enterprise may act as a brake on the development of emerging or already established cooperative relationships. Too low a level of geographical proximity characterizing relationships among entities means the lack of a certain group of common conditions 


\section{ENTREPRENEURSHIP AND SUSTAINABILITY ISSUES}

ISSN 2345-0282 (online) http://jssidoi.org/jesi/

2020 Volume 8 Number 2 (December)

http://doi.org/10.9770/jesi.2020.8.2(7)

determining the nature of their activities. However, too large a level of geographical proximity may have an equally negative impact on the activities of cooperating enterprises (Malmberg \& Maskell, 1997; Boschma, 2005a).

\subsection{Proximity in industrial clusters}

The concept of proximity can be superimposed on the concepts developed so far in the literature of the cooperation of economic entities embedded in a specific territory, which all emphasize the inseparable link between geographical proximity and other dimensions of proximity.

The vision of the industrial district is an example of an almost complete approach to the issue of synergies occurring among business entities (in terms of the scope of including factors related to various dimensions of proximity). In Marshall's industrial districts (Marshall, 1890), as in the Italian industrial districts (Pyke et al. 1990; Becattini 2002; Bellandi, 2002; Sforzi, 2002), next to the obvious connections between the concept of the district and geographical proximity, threads can be seen highlighting the importance of other dimensions of proximity. The different dimensions of proximity: cognitive (knowledge spillovers, the similarity of entities in terms of their set of competences and used technology, as well as their complementary diversity), social (relatively stable relationships among entities), organizational (phases and technically divisible production processes implemented in the cooperation of entities) and institutional (anchored in the local system of values and norms) play the role of pillars in the industrial district arising from the foundation of geographical proximity. The group of theories of regional development based on knowledge and innovation (Martin, 2003) are focused to the greatest extent on the threads which emphasize the role of cognitive proximity (appearing primarily in the context of innovation and pro-innovation activities), which does not mean, however, that they ignore the role of other dimensions of proximity. Nevertheless, each of these concepts emphasizes a different dimension of proximity. Cognitive proximity plays a key role in the concept of the learning region (Florida, 1995; Asheim, 1996; Morgan, 1997). This concept puts special emphasis on the mechanisms and processes responsible for the relative overlap of the competency sets of entities operating in a specific area. The concept of the innovative milieu (Aydalot, 1986; Camagni, 1991; Maillat, 1998) emphasizes social and institutional proximity - that is, networks of informal social contacts based on trust, developing on a common socio-cultural basis. A similar accent can be found in concepts emphasizing the systemic dimension of innovation: regional innovation system RIS (Braczyk et al. 1998; Cooke 2001; Doloreux \& Parto, 2005) or innovation ecosystem (Adner, 2006; Autio \& Thomas, 2014). They pay attention to the role of institutions and the relations among actors - in the RSI concept, the links between entities (social and organizational proximity), and the processes of generating and diffusing knowledge (cognitive proximity) are spotlighted, but additional emphasis is placed on the culture and institutions which determine the cooperation of entities (connected to institutional proximity). In the innovation ecosystem concept, proximity appears primarily in the organizational (the division of work among organizations based on their specialization), cognitive (the complementarity of knowledge and skills) and social (the interrelationships of system components) dimensions, while the rank of geographical and institutional proximity is slightly lower compared to the other discussed concepts.

In the cluster concept developed by Porter $(1998 ; 2000 ; 2008)$, individual dimensions of proximity can also be highlighted. Already through the very definition of the cluster, Porter linked threads of geographical proximity (a geographical cluster of entities of various types), organizational proximity (the fact of participation in the same higher-order structure), social proximity (the simultaneous cooperation and competition of the entities forming the cluster), cognitive proximity (the similarity of competences related to belonging to the same sector) and institutional proximity (broadly understood as the cultural and administrative bases for conducting business by the entities involved in a given cluster). However, cluster organizations are separate entities and cannot be identified with clusters. They should be understood as formally established organizations which function at a higher level of aggregation, are composed of institutional members that have joined them purposefully, and act actively in order 
to achieve some collective or individual objectives (Lis, 2018). Cluster organizations, also referred to in the literature as bottom-up clusters or cluster initiatives, are focused on supporting the development of a given cluster (Sölvell et al., 2003; Lindqvist et al., 2013). Due to the obvious connotations with the cluster (the CO concept has grown on the foundations of the cluster concept), the $\mathrm{CO}$ is based on similar types of proximity (primarily, the geographical and institutional dimensions), although they may be slightly differently shaped (this applies especially to proximity in the social, cognitive and organizational dimensions). The differences between the cluster and the cluster organization can also be manifested in the relationships occurring between individual dimensions of proximity.

\section{Methodology}

\subsection{Conceptual assumptions}

The qualitative research on which the current research is based was conducted by Lis in 2016. As a result of this prior research, two theoretical concepts were generated (Lis, 2018). These concepts are interrelated, hence they can be treated as one coherent theoretical concept, allowing for a better understanding and explanation of the mechanisms of cooperation in COs. The first concept covers the trajectory of the development of cooperative relationships in COs, while the second one concerns the development of proximity in such organizations. As part of the first developed concept, four main levels of cluster cooperation were identified, with regard to "the main objectives", indicating the key type of activity in COs (Tab. 1). The second concept, raised to a higher level of abstraction and applied to the first concept, explains how proximity can support the development of cooperation in COs. The research results have proved that different dimensions of proximity strongly affect every single identified level of cooperation. In turn, cooperation at every level causes the development of proximity in various dimensions. This is reflected in the objectives defined at individual levels of cooperation that correspond to different types of proximity, and therefore their achievement may mean the development of proximity in a specific (assigned to a given level) dimension. In Table 1, each level of cooperation has been assigned defined objectives and dimensions of proximity have been identified at the entry and exit levels.

Table 1. Levels of the development of cooperation in cluster organizations

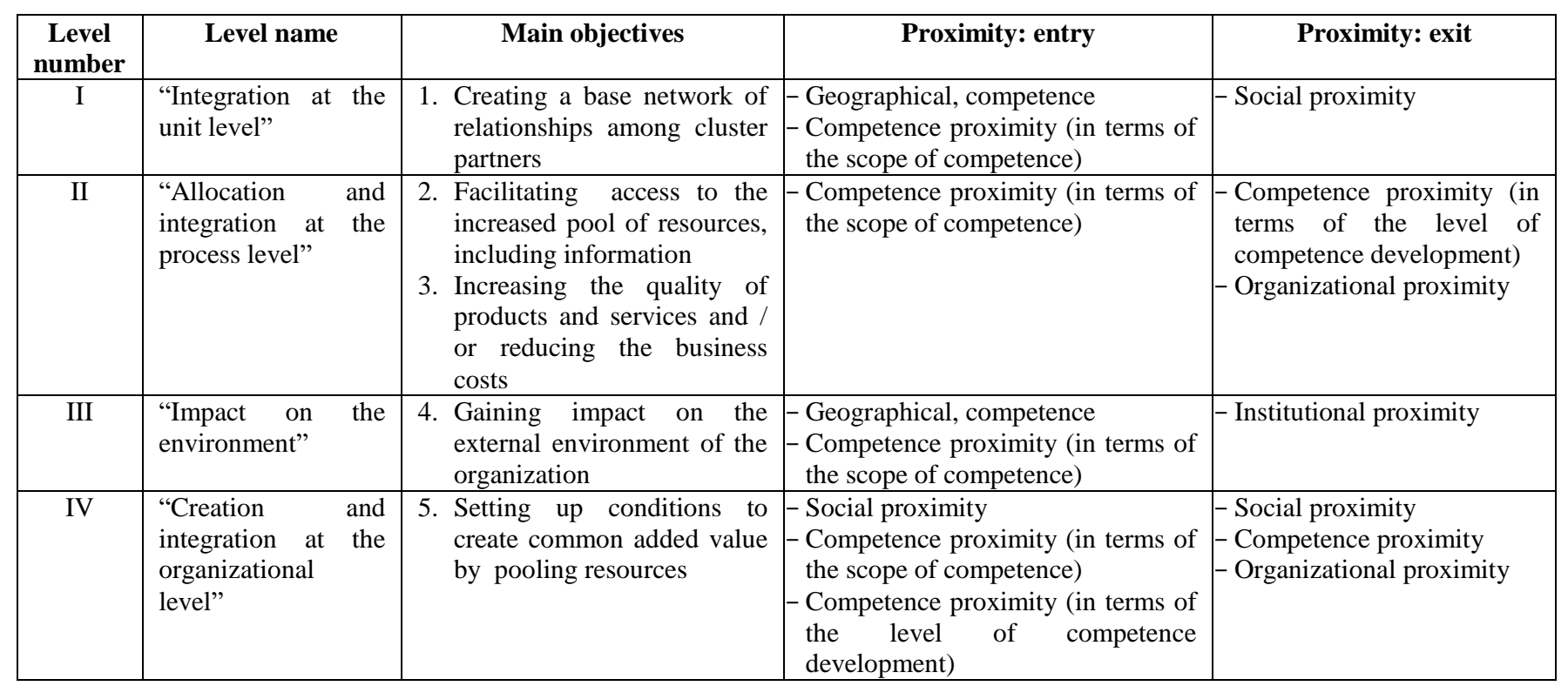


All the conceptual categories used to create both generated concepts were based on the conducted qualitative research. The individual elements of the concepts were therefore not a preconceived idea, but constituted the best theoretical explanation of the tendencies observed from the qualitative research in the analyzed organizations. The identified dimensions of proximity basically coincided with the classic Boschma division (2004; 2005a; 2005b), with the exception of cognitive proximity. The results of the empirical research showed that - in need of a better explanation of the development of cooperation in the studied $\mathrm{COs}$ - it would be necessary to slightly differentiate proximity in this dimension. Based on the research, it could be seen that the relationships among cluster entities were shaped differently when their similarity was visible in the scope of their competences, and differently when this similarity related to the level of advancement of these competences. The above observation led to the distinction of a completely new dimension of proximity: "competence proximity" (taking into account both the scope of competences and the level of competence development) in place of "cognitive proximity".

Moving along the developed trajectory for the development of cooperation in COs (going from level I to level IV), relationships among different types of proximity were identified: the development of cooperative relationships in $\mathrm{COs}$ is determined by geographical and competence proximity (in terms of the scope of competences), on the basis of which (with the commitment of cluster entities) social and institutional proximity are developed, followed by competence proximity (in terms of the level of competence development) and organizational proximity (Fig. 1). In the developed model, in addition to proximity in various dimensions, an additional variable emerged on the basis of the qualitative research: the commitment of cluster members in activities undertaken as part of the CO.

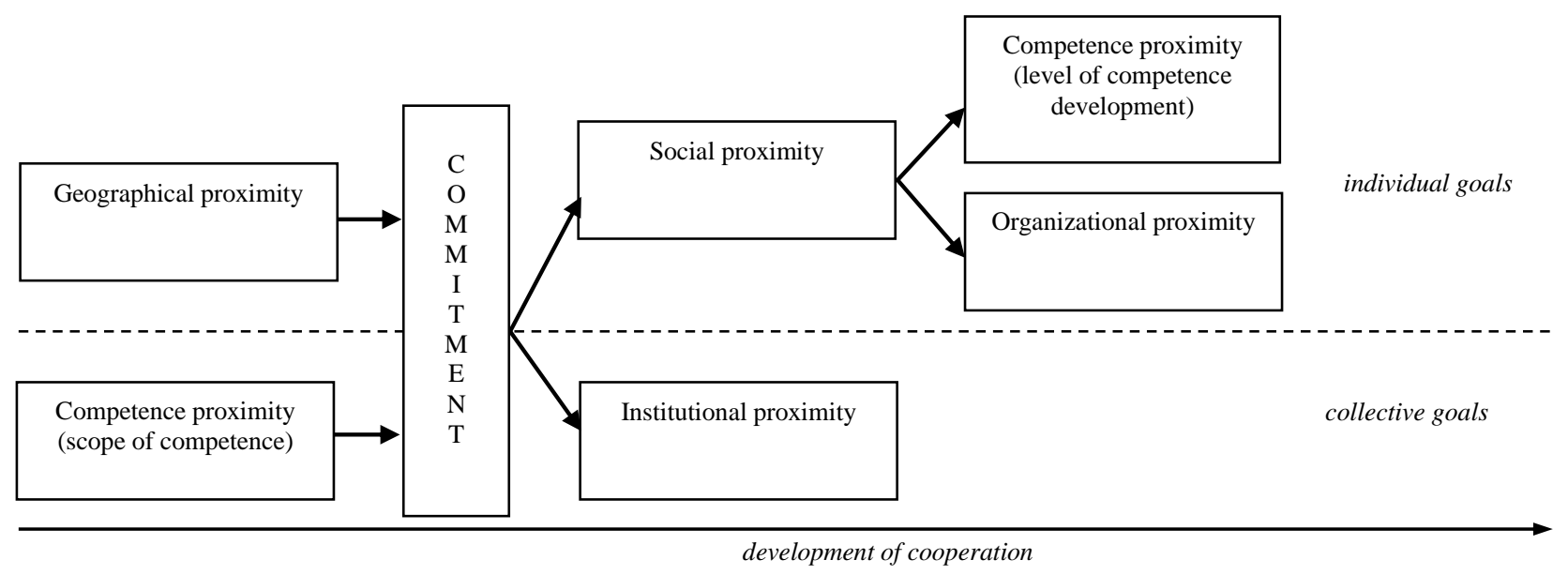

Figure 1. Links between dimensions of proximity

Source: Lis, 2018.

\subsection{Research hypotheses}

The combination of levels of cooperation with the specific proximity dimensions expected at the "entry" and "exit" of a given level, with linking together the identified dimensions of proximity, allows the analysis of proximity in dynamic terms. This gives rise to the formulation of two research hypotheses (additionally divided into constituent hypotheses), reflecting the complex nature of the cause-effect relationships occurring between selected dimensions of proximity in COs (Table 2). The $\mathrm{H} 1$ and $\mathrm{H} 2$ hypotheses focus only on three successive 
levels (I, II, IV), best illustrating the development of cooperation in COs. The hypotheses do not take into account level III, referring to the relationships among cluster members and external entities (from outside the $\mathrm{CO}$ ). The qualitative research shows that institutional proximity (responsible for achieving objectives at level III) plays an insignificant role in the development of inter-organizational cooperation.

Table 2. Research hypotheses

\begin{tabular}{|c|c|}
\hline $\begin{array}{c}\text { Research hypotheses } \\
\end{array}$ & $\begin{array}{l}\text { Constituent hypotheses } \\
\end{array}$ \\
\hline \multirow{4}{*}{$\begin{array}{l}\text { H1. Social proximity created on the basis of } \\
\text { geographical proximity has a positive impact on the } \\
\text { development of competence proximity (in terms of } \\
\text { the level of competence development) and } \\
\text { organizational proximity. }\end{array}$} & $\begin{array}{l}\text { H1.1. Geographical proximity has a positive effect on the } \\
\text { development of social proximity. }\end{array}$ \\
\hline & $\begin{array}{l}\text { H1.2. Social proximity has a positive impact on achieving the } \\
\text { objectives directly related to the development of competence } \\
\text { proximity (in terms of the level of competence development) and } \\
\text { organizational proximity. }\end{array}$ \\
\hline & $\begin{array}{l}\text { H1.3. Social proximity has a positive impact on gaining access to } \\
\text { information and knowledge, determining the development of } \\
\text { competence proximity (in terms of the level of competence } \\
\text { development). }\end{array}$ \\
\hline & $\begin{array}{l}\text { H1.4. The achievement of the objectives directly related to the } \\
\text { development of competence proximity (in terms of the competence } \\
\text { development level) and organizational proximity positively affects } \\
\text { the access to information and knowledge. }\end{array}$ \\
\hline \multirow{2}{*}{$\begin{array}{l}\text { H2: Geographical proximity is important for the } \\
\text { constitution and development of a cluster } \\
\text { organization because it has a positive impact on the } \\
\text { commitment of cluster members, which - in turn - } \\
\text { has a positive impact on the development of social } \\
\text { proximity. }\end{array}$} & $\begin{array}{l}\text { H2.1. Geographical proximity has a positive impact on the } \\
\text { commitment of cluster members. }\end{array}$ \\
\hline & $\begin{array}{l}\text { H2.2. The commitment of cluster members has a positive impact } \\
\text { on the development of social proximity. }\end{array}$ \\
\hline
\end{tabular}

Source: Lis, 2018.

The relationships described in the form of the $\mathrm{H} 1$ and $\mathrm{H} 2$ hypotheses form two multidimensional conceptual models, tested in this paper (Fig. 2) (the separation of the H1 and H2 hypotheses was due to conceptual and methodological reasons).

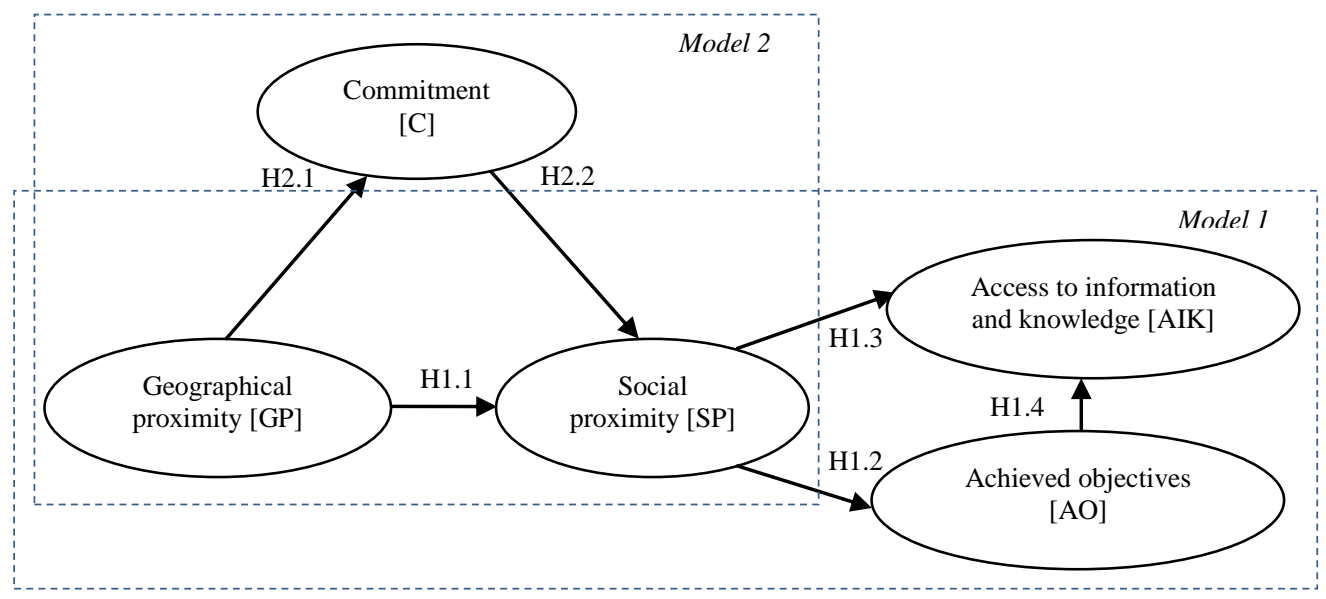

Figure 2. Conceptual models Source: Lis, 2018. 


\section{ENTREPRENEURSHIP AND SUSTAINABILITY ISSUES}

ISSN 2345-0282 (online) http://jssidoi.org/jesi/ 2020 Volume 8 Number 2 (December) http://doi.org/10.9770/jesi.2020.8.2(7)

\subsection{Operationalization}

The latent variables used in both models were operationalized by selecting the appropriate observable indicators, and additionally using exploratory factor analysis. An ordinal scale (5-point Likert scale) was used to measure the variables. In Model 1, a total of 4 latent constructs were used, described using 15 observable indicators. To measure geographical proximity [GP], three variables were used to refer to the physical distance among cluster entities. Social proximity [SP] was described by three variables showing the process of creating bonds among cluster members: starting from the development of relationships, through trust building, to the verification of trust based on the experience of cooperation. Another variable - achieved objectives [AO] - in the proposed conceptual model was reduced to three objectives directly related to the development of competence proximity (objective 1 - corresponding to level II) and organizational proximity (objective 2 - level II, objective 3 - level IV). The last variable in the model - access to information and knowledge [AIK] (determining the development of competence proximity in the discussed aspect) - was described using six observable variables.

Model 2 uses 3 latent constructs (described using in total 14 observable indicators): geographical and social proximity (appearing in Model 1) and commitment [C], measured on the basis of eight observable variables corresponding to individual levels of cooperation in COs (the two most characteristic forms of commitment for each level).

\subsection{Research sample}

The research was carried out in 2017 in four purposefully selected cluster organizations in Poland. The same COs that participated in the earlier qualitative research (2016) were selected for the quantitative research. In the selection of COs the extreme cases approach was used to ensure maximum variability and diversity within the research field. Taking the economic sector as the main differentiating criterion, the research was conducted in two COs representing the ICT industry (Mazovia Cluster ICT [MC ICT] and Interizon: Pomeranian Region ICT Cluster) and two from the metal industry (Metal Cluster of Lubuskie Province [MCLP] and Metal Working Eastern Cluster [MWEC]).

The surveyed cluster organizations are formal organizations that were launched at a similar time (in the period 2007-2009). They also have a similar, regional scope of activity. However, they differ in the way they were established. All four COs wre created as a result of a large involvement of the enterprises, but only one of them (MCLP) is considered a bottom-up initiative, while the other three are mixed forms. In addition, COs representing the ICT sector are much larger than metal COs (the number of members in the studied COs in the analyzed period was: MCLP - 35, MWEC - 78, MC ICT - 200, and Interizon - 130). The research covered 132 cluster enterprises: 51 from metal COs (38 from MWEC and 13 from MCLP) and 81 from ICT COs (45 from MC ICT and 36 from Interizon).

\subsection{Techniques for collecting and analyzing data}

The basic technique for collecting data was an online questionnaire. Both theoretical models were tested using structural equation modeling. In the analysis, the two-step sequential approach of Anderson-Gerbing $(1988 ; 1992)$ was used. Exploratory factor analysis and confirmatory factor analysis were used to test measurement models. Both analyses were performed using the maximum likelihood estimator and were based on the value of the KMO (Kaiser-Meyer-Olkin) measure of sampling adequacy. After testing the validity of the measures of the measurement models, structural models were constructed and all dependency paths in these models were analyzed, which allowed the research hypotheses to be tested. 


\section{Research results}

\subsection{Model 1}

In the case of Model 1, exploratory factor analysis showed a very large fit of observable variables to latent constructs (the value of the KMO measure of sampling adequacy was 0.818 , Bartlett's sphericity test was statistically significant, $\mathrm{p}<0.001)$. The main analysis used to verify the conceptual model was, however, confirmatory factor analysis (CFA). The value of $\chi^{2}$ was $150.25(\mathrm{DF}=84)$, while the value of CMIN / DF was 1.79. The RMR was achieved at an acceptable level of 0.07 , as was the RMSEA approximation error, which reached 0.078 (which is within the acceptable limits, but within the upper limit for a good fit). The CFI and TLI exceeded the minimum 0.9 values adopted for well-matched models (Table 3 ).

Table 3. Confirmatory factor analysis results for Model 1

\begin{tabular}{|c|c|c|c|c|c|c|c|}
\hline \multirow{2}{*}{ Variables } & \multirow{2}{*}{ Cronbach's $\alpha$} & \multirow{2}{*}{$\mathbf{C R}$} & \multirow{2}{*}{ AVE } & \multicolumn{4}{|c|}{ Correlations between variables } \\
\hline & & & & [GP] & [SP] & [AO] & [AIK] \\
\hline Geographical proximity [GP] & 0,83 & 0,85 & 0,67 & 0,82 & & & \\
\hline Social proximity $[\mathrm{SP}]$ & 0,77 & 0,78 & 0,54 & 0,28 & 0,73 & & \\
\hline Achieved objectives [AO] & 0,82 & 0,82 & 0,6 & 0,11 & 0,26 & 0,77 & \\
\hline Access to information and knowledge [AIK] & 0,91 & 0,91 & 0,64 & 0,17 & 0,7 & 0,44 & 0,80 \\
\hline
\end{tabular}

$\chi^{2}=150,25(\mathrm{DF}=84) ; \mathrm{CFI}=0,94 ; \mathrm{TLI}=0,92 ; \mathrm{RMSEA}=0,078(90 \% \mathrm{CI}=0,057-0,097) ; \mathrm{RMR}=0,07 ; \mathrm{CMIN} / \mathrm{DF}=1,79 ; \mathrm{AIC}=222,25 ; n=132$

Source: the author.

The standardized value of factor loadings of all adopted observable variables exceeded 0.5 , and the vast majority (except for [GP3] and [SP3]) also 0.7 (all factor loadings were also statistically significant, $\mathrm{p} \leq 0.001$ ). The AVE indicator calculated for each latent variable exceeded the recommended value of 0.5 . The reliability measures: Cronbach's $\alpha$ and CR for each construct exceeded the limits of 0.7. All of the fit and convergence indicator values used exceeded their acceptability thresholds (Hair et al., 2014), which decided on the measurement model to adopt for the structural modeling process.

A structural model was then built in which the interaction between latent variables was assessed. Based on the conducted analysis, it was determined that Model 1 achieved the recommended degree of fit (Table 4).

Table 4. Path analysis results for Model 1

\begin{tabular}{|c|c|c|c|c|}
\hline Hypotheses & $\boldsymbol{\beta}$ & $t$ & $p$ & $\begin{array}{l}\text { Acceptance/ } \\
\text { rejection }\end{array}$ \\
\hline H1.1. Geographical proximity [GP] $\rightarrow$ Social proximity [SP] & 0,27 & 2,53 & 0,011 & A \\
\hline H1.2. Social proximity $[\mathrm{SP}] \rightarrow$ Achieved objectives $[\mathrm{AO}]$ & 0,27 & 2,44 & 0,015 & A \\
\hline H1.3. Social proximity [SP] $\rightarrow$ Access to information and knowledge [AIK] & 0,62 & 5,35 & 0,000 & A \\
\hline H1.4. Achieved objectives $[\mathrm{AO}] \rightarrow$ Access to information and knowledge [AIK] & 0,28 & 3,23 & 0,001 & A \\
\hline
\end{tabular}

Legenda: $\chi^{2}=150,58(\mathrm{DF}=86) ; \mathrm{CFI}=0,94 ; \mathrm{TLI}=0,93 ; \mathrm{RMSEA}=0,076(90 \% \mathrm{CI}=0,055-0,095) ; \mathrm{RMR}=0,07 ; \mathrm{CMIN} / \mathrm{DF}=1,75 ; n=132$

Source: the author.

The analysis of the paths did not give rise to the rejection of the H1.1-H1.4 hypotheses (all four paths proved to be statistically significant). It was established that geographical proximity had a positive impact on social proximity, which supported the H1.1 hypothesis. Social proximity had a positive impact on the achieved objectives, related in this case - to competence proximity (in terms of the level of competence development) and organizational proximity, which in turn supported the H1.2 hypothesis. The very high $\beta$ value associated with the H1.3 
hypothesis supports the argument about the strong positive impact of social proximity on access to information and knowledge. It was also confirmed that the achieved objectives had a positive impact on access to information and knowledge in the studied COs (support for the H1.4 hypothesis), which contributed to the further development of competence proximity (in the indicated aspect).

\subsection{Model 2}

In the case of Model 2, exploratory factor analysis also showed a large fit of the developed constructs $(\mathrm{KMO}=$ 0.861, the Bartlett sphericity test was statistically significant, $\mathrm{p}<0.001)$. Based on confirmatory factor analysis, the initial model was slightly modified. Modification indexes have shown that it is worth correlating the latent residual variables in the construct "commitment" [C] (due to the high covariance values: e4 with e5, e5 with e9, e10 with e11). This allowed the model to be improved to fit to the planned constructs in accordance with the made assumptions*. After the above modification, the values of all indicators adopted for analysis fit within the recommended ranges: $\chi 2$ - 123.18 (DF = 71), CMIN / DF - 1.73, RMR - 0.061, RMSEA - 0.075. The incremental fit indices were higher than 0.9: CFI reached 0.96 and TLI reached 0.95 (Table 5).

Table 5. Confirmatory factor analysis results for Model 2

\begin{tabular}{|c|c|c|c|c|c|c|}
\hline \multirow{2}{*}{ Variables } & \multirow{2}{*}{ Cronbach's $\alpha$} & \multirow{2}{*}{ CR } & \multirow{2}{*}{ AVE } & \multicolumn{3}{|c|}{ Correlations between variables } \\
\hline & & & & [GP] & {$[\mathbf{C}]$} & {$[\mathbf{S P}]$} \\
\hline Geographical proximity [GP] & 0,83 & 0,85 & 0,67 & 0,82 & & \\
\hline Commitment $[\mathrm{C}]$ & 0,93 & 0,93 & 0,64 & 0,34 & 0,80 & \\
\hline Social proximity [SP] & 0,77 & 0,78 & 0,54 & 0,27 & 0,60 & 0,73 \\
\hline
\end{tabular}

$\chi^{2}=123(\mathrm{DF}=71), 18 ; \mathrm{CFI}=0,96 ; \mathrm{TLI}=0,95 ; \mathrm{RMSEA}=0,075$ (90\%CI=0,052-0,097); RMR=0,061; CMIN/DF=1,73; AIC=191,18; $n=132$

Source: the author.

Tests on the accuracy of the proposed model were also successful: standardized factor loadings reached values higher than the acceptable level of 0.5, and almost all (with the same exceptions as in the first model, i.e. [GP3] and [SP3]) exceeded the minimum level of 0.7. For each latent variable, the AVE index value was over 0.5, while the values of Cronbach's $\alpha$ and CR coefficients were at a level exceeding the minimum threshold of 0.7 . The positive assessment results of the measurement model allowed for its adoption to the next stage - structural equation modeling.

In the next step, an assessment of the interaction between latent variables was carried out, which allowed the research hypotheses to be tested. The analysis showed a good fit of the model (Table 6).

Table 6. Path analysis results for Model 2

\begin{tabular}{|c|c|c|c|c|}
\hline Hypotheses & $\boldsymbol{\beta}$ & $\boldsymbol{t}$ & $\boldsymbol{p}$ & $\begin{array}{c}\text { Acceptance/ } \\
\text { rejection }\end{array}$ \\
\hline H2.1. Geographical proximity [GP] $\rightarrow$ Commitment [C] & 0,34 & 3,66 & 0,000 & $\mathrm{~A}$ \\
\hline H2.2. Commitment [C] -> Social proximity [SP] & 0,60 & 5,84 & 0,000 & $\mathrm{~A}$ \\
\hline
\end{tabular}

$\chi^{2}=123,93(\mathrm{DF}=72) ; \mathrm{CFI}=0,96 ; \mathrm{TLI}=0,95 ; \mathrm{RMSEA}=0,074(90 \% \mathrm{CI}=0,051-0,096) ; \mathrm{RMR}=0,064 ; \mathrm{CMIN} / \mathrm{DF}=1,72 ; n=132$

Source: the author.

\footnotetext{
* The values of the indicators before the modification were: $\chi^{2}=186,23(\mathrm{DF}=74)$; CFI=0,91; TLI=0,89; RMSEA=0,11 (90\% CI=0,088 $0,127) ; \mathrm{RMR}=0,067 ; \mathrm{CMIN} / \mathrm{DF}=2,52 ; \mathrm{AIC}=248,23 ; n=132$.
} 


\section{ENTREPRENEURSHIP AND SUSTAINABILITY ISSUES}

ISSN 2345-0282 (online) http://jssidoi.org/jesi/ 2020 Volume 8 Number 2 (December) http://doi.org/10.9770/jesi.2020.8.2(7)

The path analysis did not give grounds for rejecting the hypotheses $\mathrm{H} 2.1-\mathrm{H} 2.2$. The $\beta$ value associated with the H2.1 hypothesis confirmed the statistically significant, positive impact of geographical proximity on the commitment manifested at all identified levels of cooperation in the COs. In turn, the commitment had a statistically significant, strong, positive impact on the development of social proximity, which supported the $\mathrm{H} 2.2$ hypothesis. This means that an increase in commitment in the activities within a $\mathrm{CO}$ will result in the development of relationships among cluster partners and vice versa - a decrease in involvement will weaken those relationships.

\section{Discussion}

Both conceptual models - Model 1 (based on the H1 hypothesis) and Model 2 (described by the H2 hypothesis), proved to be valid under the conditions of the study. The relationships between variables reflected in Models 1 and 2 show the development of proximity in a CO. Geographical proximity is conducive to the development of social proximity, taking into account the commitment factor. The short distance among cluster entities enables involvement in activities undertaken at various levels of cluster cooperation (I-IV), manifested through the personal contact of persons representing cluster members, which in turn leads to the development of increasingly stronger relationships within the CO. This in turn causes the development of competence proximity (in terms of the level of competence development) and organizational proximity. This means that as the distance among cluster entities decreases, the potential for developing relationships among them (social proximity) increases, which consequently increases the similarities in the competence systems of these entities in terms of their levels of competence (competence proximity, in the analyzed aspect) as well as in their internal structures and the existing degree of inter-organizational interdependencies (organizational proximity).

The obtained research results therefore support the thesis regarding the primacy of geographical proximity over other dimensions of proximity, but at the initial stages of the development of cooperative relations in COs. Geographical proximity turns out to be the most fundamental dimension in initiating cluster cooperation because it provides the basis for the formation and development of proximity in other dimensions. However, along with the gradual transition to higher levels of cooperation, the importance of a common location for the effects of cooperation undertaken by cluster enterprises decreases. This causes a decrease in the rank of geographical proximity, giving way to other dimensions of proximity, especially social and competence (in terms of the level of competence development) dimensions, which increase as a result of developing relationships that guarantee better access to resources, primarily to knowledge and information. At the highest level, to undertake the most advanced forms of cooperation, leading to the gradual organizational integration of cluster partners (and thus the development of organizational proximity), a high level of trust and a high, and at the same time, very similar level of competence among the cooperating entities are already required. Therefore, the higher the level of cluster cooperation, in conjuction with the development of proximity in the social, cognitive, and organizational dimensions, the greater the synergy effect resulting from this cooperation, and thus the sustainable development of the entire cluster structure can be.

\section{Conclusions}

The connection of the very current contemporary issue of clustering within the extremely rarely undertaken aspect of cluster organizations with the concept of proximity has no equivalent in the literature. Since no similar publications have been found in the existing literature combining the issue of proximity with the concept of the cluster organization (or cluster initiative), it is impossible to find scientific publications that would simultaneously address the three issues mentioned above: (cluster organizations - the development of cooperation - proximity). Relying on four COs representing two very different sectors of the economy, and using them to test the relationships between the four dimensions of proximity selected from among the five identified in the previously 


\section{ENTREPRENEURSHIP AND SUSTAINABILITY ISSUES}

ISSN 2345-0282 (online) http://jssidoi.org/jesi/ 2020 Volume 8 Number 2 (December) http://doi.org/10.9770/jesi.2020.8.2(7)

conducted qualitative research significantly enriches the existing achievements in the area of the discussed issues. In addition, the results of the research take into account the assumptions regarding the dynamics of proximity. The reasoning behind combining the identified levels of cooperation in COs with the specific dimensions of proximity necessary "at the entry" and those arising or developing "at the exit" of each of these levels is an example of considering the dynamic aspect of proximity.

The empirical findings can also provide some practical implications for public authorities, cluster coordinators, as well as for cluster members. Politicians responsible for shaping cluster-based policy at various levels, taking care of sustainable cluster development, should launch instruments of cluster policy that would strengthen the development of proximity, especially in the cognitive and organizational dimension. This applies in particular to supporting innovation, because the lack of investment in innovation can lead to the process of decline of economic competitiveness (e.g. Bonetto et al., 2014), and event the declay of the whole cluster. In the case of cluster coordinators, the concern for sustainable development of partner cooperation within a cluster organization should be manifested in undertaking conscious and intentional activities leading to achieving ever higher levels of cooperation (from I to IV) and motivating cluster members to engage in these activities. Finally, cluster members, wanting to achieve the synergy effect resulting from cluster cooperation within the $\mathrm{CO}$, should strive to create more or less informal relationships, which can translate into the development of proximity in other dimensions.

The research has three main limitations. The first limitation is the relatively small and not very diverse research sample. This, therefore, does not allow the findings to be generalized. Nevertheless, the applied logic of sample selection according to the extreme cases approach (the sector as a differentiating criterion) allows the thesis to be put forward regarding a wider universality of the discovered regularities. The second limitation is the subjectivity inscribed in the specifics of research conducted in the field of social sciences. This also applies to the quantitative research carried out in the proposed form. The problem of subjectivity in the study was partially solved, as the quantitative research was a continuation of the previously conducted qualitative research. Thus it can be considered a kind of triangulation of source data and research methods. The third limitation concerns the structural equation modeling used to test the hypotheses (H1-2). An important limitation is the size of the research sample adopted in the quantitative research because drawing conclusions based on the results of structural modeling is only possible if stringent methodological assumptions regarding sample size are met. There is no consensus on the minimum sample size in SEM - it is most often dependent on the complexity of the model (Hair, 2014; Anderson \& Gerbing, 1988; 1992). The number of variables in the analyzed models in relation to the number of observations should not raise any objections, the more so in that both developed conceptual models were well fit and the defined variables proved to be reliable.

From the viewpoint of the replication of results, the research should be repeated on a representative, large, random sample, taking into account additional sectors of the economy, using the same measurement tools. This would allow the confirmation of theoretical constructs, and in the case of obtaining results consistent with those obtained in the conducted research - reveal the universality of the observed relationships. In future studies, it would also be necessary to carry out an estimation of mediation in both models (omitted in this paper). In Model 1, two variables can play the role of mediator: "social proximity" [SP] or "achieved objectives" [AO]; in Model 2 "commitment" [C]. In order to increase the universality of the developed concept of proximity, it should also be considered to include new comparative groups in the research. 


\section{ENTREPRENEURSHIP AND SUSTAINABILITY ISSUES}

ISSN 2345-0282 (online) http://jssidoi.org/jesi/ 2020 Volume 8 Number 2 (December) http://doi.org/10.9770/jesi.2020.8.2(7)

\section{References}

Adner, R. 2006. Match your innovation strategy to your innovation ecosystem, Harvard Business Review 84(4): 98-107.

Anderson, J. C., \& Gerbing, D. W. 1988. Structural equation modeling in practice: A review and recommended two-step approach, Psychological Bulletin 103(3): 411.

Anderson, J. C., \& Gerbing, D. W. 1992. Assumptions and comparative strengths of the two-step approach: Comment on Fornell and Yi, Sociological Methods \& Research 20(3): 321-333. https://doi.org/10.1177/0049124192020003002

Asheim, B. R. T. 1996. Industrial districts as 'learning regions': a condition for prosperity, European Planning Studies 4(4): 379-400. https://doi.org/10.1080/09654319608720354

Autio, E., \& Thomas, L. D. W. 2014. Innovation ecosystems: Implications for innovation management?, in Dodgson M., Gann D., Phillips N. (Eds.). The Oxford Handbook of Innovation Management. Oxford, UK: Oxford University Press, 204-228.

Aydalot, P. (Ed.) 1986. Milieux innovateurs en Europe. Paris: GREMI.

Bahlmann, M. D. 2016. Finding value in geographic diversity through prior experience and knowledge integration: a study of ventures' innovative performance, Industrial and Corporate Change 25(4): 573-589. https://doi.org/10.1093/icc/dtv041

Balland, P. A., Boschma, R., \& Frenken, K. 2015. Proximity and innovation: From statics to dynamics, Regional Studies 49(6): 907-920. https://doi.org/10.1080/00343404.2014.883598

Balog, M. 2016. Development Factors of Cluster Organizations in the Slovak Republic, EKONOMICKY CASOPIS 64(2): 149-168.

Becattini, G. 2002. Industrial sectors and industrial districts: Tools for industrial analysis, European Planning Studies 10(4): 483-493. https://doi.org/10.1080/09654310220130194

Bellandi, M. 2002. Italian industrial districts: An industrial economics interpretation, European Planning Studies 10(4): 425-437. https://doi.org/10.1080/09654310220130158

Bonetto, P., Hofmann, B., Prause, G. 2014. Rise and fall of the Lyon silk cluster: a case study about entrepreneurial sustainability, Entrepreneurship and Sustainability Issues 2(1): 1-11. https://doi.org/10.9770/jesi.2014.2(1)

Boschma, R. 2004. Proximité et innovation, Économie Rurale 280(1): 8-24.

Boschma, R. 2005a. Proximity and innovation: A critical assessment, Regional Studies 39(1): 61-74. https://doi.org/10.1080/0034340052000320887

Boschma, R. 2005b. Role of proximity in interaction and performance: Conceptual and empirical challenges, Regional Studies 39(1): 4145. https://doi.org/10.1080/0034340052000320878

Boschma, R., Balland, P.-A., \& de Vaan, M. 2014. The formation of economic networks: A proximity approach, in Torre A., Wallet F. (Eds.). Regional development and proximity relations. Cheltenham: Edward Elgar, 243-267.

Boschma, R.A., \& Frenken, K. 2010. The spatial evolution of innovation networks. A proximity perspective, in Boschma R. A., Martin R. (Eds.). Handbook on evolutionary economic geography. Cheltenham: Edward Elgar, 120-135.

Braczyk, H. J., Cooke, P. N., \& Heidenreich, M. (Eds.). 1998. Regional innovation systems: the role of governances in a globalized world. Psychology Press.

Broekel, T., \& Boschma, R. 2012. Knowledge networks in the Dutch aviation industry: the proximity paradox, Journal of Economic Geography 12(2): 409-433. https://doi.org/10.1093/jeg/lbr010

Camagni, R. 1991. Introduction: From the local "milieu" to innovation through cooperation networks, in Camagni R. (Ed.). Innovation networks: Spatial perspectives. London: Belhaven Press, 1-9. 


\section{ENTREPRENEURSHIP AND SUSTAINABILITY ISSUES}

ISSN 2345-0282 (online) http://jssidoi.org/jesi/ 2020 Volume 8 Number 2 (December) http://doi.org/10.9770/jesi.2020.8.2(7)

Cohen, W. M., \& Levinthal, D. A. 1990. Absorptive capacity: A new perspective on learning and innovation, Administrative Science Quarterly 35(1): 128-152. doi:10.2307/2393553

Cooke, P. 2001. Regional innovation systems, clusters, and the knowledge economy, Industrial and Corporate Change 10(4): 945-974. https://doi.org/10.1093/icc/10.4.945

Courlet, C. 1994. Les systèmes productifs localisés. De quoi parle-t-on?, in Courlet C., Soulage B. (Eds.). Industrie, territoires et politiques publiques. Paris: Editions L'Harmattan, 13-32.

Doloreux, D. 2002. What we should know about regional systems of innovation, Technology in Society 24(3): 243-263. https://doi.org/10.1016/S0160-791X(02)00007-6

Doloreux, D., \& Parto, S. 2005. Regional innovation systems: Current discourse and unresolved issues, Technology in Society 27(2): 133153. https://doi.org/10.1016/j.techsoc.2005.01.002

Dosi, G., \& Nelson, R. R. 1994. An introduction to evolutionary theories in economics, Journal of Evolutionary Economics 4(3): 153-172. https://doi.org/10.1007/BF01236366

Fitjar, R. D., Huber, F., \& Rodríguez-Pose, A. 2016. Not too close, not too far: Testing the Goldilocks principle of 'optimal'distance in innovation networks, Industry and Innovation 23(6): 465-487. https://doi.org/10.1080/13662716.2016.1184562

Florida, R. 1995. Toward the learning region, Futures 27(5): 527-536.

Gilly, J. P., \& Torre, A. 2000. Proximity relations. Elements for an analytical framework, in Green M. B., McNaughton R.B. (Eds.). Industrial networks and proximity. Aldershot: Ashgate Publishing, 1-16.

Guerini, M., Bonaccorsi, A., Colombo, M.G., Rossi-Lamastra, C. 2013. The role of geographical, social and cognitive proximity in collaborations between high-tech entrepreneurial ventures and universities. 35th DRUID Celebration Conference, Barcelona, Spain, June $17-19$.

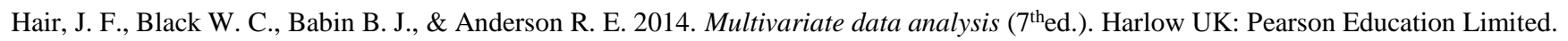

Hansen, T. 2015. Substitution or overlap? The relations between geographical and non-spatial proximity dimensions in collaborative innovation projects, Regional Studies 49(10): 1672-1684. https://doi.org/10.1080/00343404.2013.873120

Hardeman, S., Frenken, K., Nomaler, Ö., \& Ter Wal, A. L. 2015. Characterizing and comparing innovation systems by different 'modes' of knowledge production: A proximity approach, Science and Public Policy 42(4): 530-548. https://doi.org/10.1093/scipol/scu070

Havierniková, K., Kordoš, M. 2019. Selected risks perceived by SMEs related to sustainable entrepreneurship in case of engagement into cluster cooperation, Entrepreneurship and Sustainability Issues 6(4): 1680-1693. https://doi.org/10.9770/jesi.2019.6.4(9)

Heringa, P. W., Horlings, E., van der Zouwen, M., van den Besselaar, P., \& van Vierssen, W. 2014. How do dimensions of proximity relate to the outcomes of collaboration? A survey of knowledge-intensive networks in the Dutch water sector, Economics of Innovation and New Technology 23(7): 689-716. https://doi.org/10.1080/10438599.2014.882139

Klimas, P. 2011. Wymiary bliskości w sieciach innowacji Przegląd Organizacji 4: 16-20.

Klimas, P. 2020. Proximity: Synthesis, Six-Dimensional Typology, and Significance for Cooperation Performance, in Contemporary Challenges in Cooperation and Coopetition in the Age of Industry 4.0. Cham: Springer, 243-272

Knoben, J., \& Oerlemans, L. A. 2006. Proximity and inter-organizational collaboration: A literature review, International Journal of Management Reviews 8(2): 71-89. https://doi.org/10.1111/j.1468-2370.2006.00121.x

Levy, R., \& Talbot, D. 2015. Control by proximity: Evidence from the 'Aerospace Valley'competitiveness cluster, Regional Studies 49(6): 955-972. https://doi.org/10.1080/00343404.2013.840721

Lindqvist G., Ketels C., \& Sölvell Ö. 2013. The Cluster Initiative Greenbook. Stockholm: Ivory Tower Publishers. 


\section{ENTREPRENEURSHIP AND SUSTAINABILITY ISSUES}

ISSN 2345-0282 (online) http://jssidoi.org/jesi/ 2020 Volume 8 Number 2 (December) http://doi.org/10.9770/jesi.2020.8.2(7)

Lis, A. M. 2019. The significance of proximity in cluster initiatives. Competitiveness Review: An International Business Journal, 29(3): 287-310. https://doi.org/10.1108/CR-08-2018-0050

Lis, A. M. 2018. Wspótpraca w inicjatywach klastrowych. Rola bliskości w rozwoju powiazań kooperacyjnych [Cooperation in cluster initiatives: the role of proximity in the development of cooperative relationships]. Gdansk: Wydawnictwo Politechniki Gdanskiej.

Lombardi, M. 2003. The evolution of local production systems: the emergence of the "invisible mind" and the evolutionary pressures towards more visible "minds", Research Policy 32(8): 1443-1462. https://doi.org/10.1016/S0048-7333(02)00157-9

Maillat, D. 1998. Innovative milieux and new generations of regional policies, Entrepreneurship \& Regional Development 10(1): 1-16. https://doi.org/10.1080/08985629800000001

Malmberg, A., \& Maskell, P. 1997. Towards an explanation of regional specialization and industry agglomeration, European Planning Studies 5(1): 25-41. https://doi.org/10.1080/09654319708720382

Malmberg, A., \& Maskell, P. 2006. Localized learning revisited, Growth and Change 37(1): 1-18. https://doi.org/10.1111/j.1468$\underline{2257.2006 .00302 . x}$

Marshall, A. 1890. Principles of Economics. London: 8th ed., Macmillan.

Martin, R. 2003. A study on the factors of regional competitiveness. A final report for the European Commission DG Regional Policy, Cambridge: University of Cambridge.

Monge, P. R., Rothman, L. W., Eisenberg, E. M., Miller, K. I., \& Kirste, K. K. 1985. The dynamics of organizational proximity, Management Science 31(9): 1129-1141. https://doi.org/10.1287/mnsc.31.9.1129

Morgan, K. 1997. The learning region: Institutions, innovation and regional renewal, Regional Studies 31(5): 491-503. https://doi.org/10.1080/00343400701232322

North, D. C. 1990. Institutions, institutional change and economic performance. Cambridge, New York: Cambridge University Press.

Paci, R., Marrocu, E., \& Usai, S. 2014. The complementary effects of proximity dimensions on knowledge spillovers, Spatial Economic Analysis 9(1): 9-30. https://doi.org/10.1080/17421772.2013.856518

Pavelkova, D., Bednar, P. \& Bialic-Davendra, M. 2015, Internationalisation activities of the cluster organisations: factors which influence them, Transformations in Business \& Economics 14(3C): 416-332.

Petruzzelli, A.M., Albino, V., \& Carbonara, N. 2009. External knowledge sources and proximity, Journal of Knowledge Management 13(5): 301-318. https://doi.org/10.1108/13673270910988123

Porter, M. E. 1998. Clusters and the new economics of competition, Harvard Business Review 76(6): 77-90.

Porter, M. E. 2000. Location, competition and economic development: Local clusters in the global economy, Economic Development Quarterly 14(1): 15-31. https://doi.org/10.1177\%2F089124240001400105

Porter, M. E. 2008. On competition. Harvard Business Press.

Pyke, F., Becattini, G., \& Sengenberger, W. (Eds.). 1990. Industrial districts and inter-firm co-operation in Italy. International Institute for Labour Studies.

Rallet, A., \& Torre, A. 1999. Is geographical proximity necessary in the innovation networks in the era of global economy?, GeoJournal 49(4): 373-380. https://doi.org/10.1023/A:1007140329027

Rice, R.E., \& Aydin, C. 1991. Attitudes toward new organizational technology: Network proximity as a mechanism for social information processing, Administrative Science Quarterly 36(2): 219-44. https://www.jstor.org/stable/2393354

Sforzi, F. 2002. The industrial district and the'new' Italian economic geography, European Planning Studies 10(4): 439-447. https://doi.org/10.1080/09654310220130167 


\section{ENTREPRENEURSHIP AND SUSTAINABILITY ISSUES}

ISSN 2345-0282 (online) http://jssidoi.org/jesi/ 2020 Volume 8 Number 2 (December) http://doi.org/10.9770/jesi.2020.8.2(7)

Singh, J. 2005. Collaborative networks as determinants of knowledge diffusion patterns, Management Science 51(5): 756-770. https://doi.org/10.1287/mnsc. 1040.0349

Sölvell, Ö., Lindqvist, G., \& Ketels, C. 2003, The cluster initiative greenbook. Stockholm: Ivory Tower.

Stam, E. 2007. Why butterflies don't leave: Locational behavior of entrepreneurial firms, Economic Geography 83(1): 27-50. https://doi.org/10.1111/j.1944-8287.2007.tb00332.x

Torre, A., \& Rallet, A. 2005. Proximity and localization, Regional Studies 39(1): 47-59. https://doi.org/10.1080/0034340052000320842

Tremblay, D. G., Fontan, J. M., Klein, J. L., \& Rousseau, S. 2003. Proximité territoriale et innovation: une enquête sur la région de Montréal, Revue dEconomie Regionale Urbaine (5): 835-852. https://doi.org/10.3917/reru.035.0835

Wuyts, S., Colombo, M. G., Dutta, S., \& Nooteboom, B. 2005. Empirical tests of optimal cognitive distance, Journal of Economic Behavior \& Organization 58(2), 277-302. https://doi.org/10.1016/j.jebo.2004.03.019

Yamada, E., \& Kawakami, T. 2015. Assessing dynamic externalities from a cluster perspective: the case of the motor metropolis in Japan, The Annals of Regional Science 54(1): 269-298. https://doi.org/10.1007/s00168-014-0654-9

Anna Maria LIS is the Associate Professor at the Gdańsk University of Technology. She is the head of the Department of Industrial Management, Faculty of Economics and Management GUT. Her scientific and research interests have been focused on problems related to institutional forms of support provided for the development of inter-organizational cooperation (including cluster organizations and business environment institutions). She has participated in many research projects implemented at academic centers, as well as in projects requested by the public authorities.

ORCID ID: orcid.org/0000-0002-1527-7796

Make your research more visible, join the Twitter account of ENTREPRENEURSHIP AND SUSTAINABILITY ISSUES:

@Entrepr69728810

Copyright (C) 2020 by author(s) and VsI Entrepreneurship and Sustainability Center

This work is licensed under the Creative Commons Attribution International License (CC BY).

http://creativecommons.org/licenses/by/4.0/

c) (7) Open Access 